\title{
Skin Tissue
}

National Cancer Institute

\section{Source}

National Cancer Institute. Skin Tissue. NCI Thesaurus. Code C33563.

Tissue composed of three layers- epidermis, dermis and subcutis which protect underlying muscles and organs. Skin is used for insulation, vitamin D production, sensation, and excretion through sweat. 